\title{
Characterisation of the Drivers of Environmental Management System Implementation
}

\author{
Olugbenga Timo Oladinrin and Lekan Damilola Ojo
}

\begin{abstract}
Purpose - The detrimental impacts of construction industry activities, viz toxicity of cement and concrete to the health of construction workers and the general public, have been reported in previous studies. Several environmental management measures were put in place by international organisations to reduce these impacts on humans and the entire ecosystem. Sadly, such environmental management measures are not widely embraced in the construction industry of developing countries. This contributes to the poor quality of life of construction stakeholders, amongst other outcomes. Therefore, this study investigated the drivers to facilitate an Environmental Management System (EMS) in the Nigerian construction industry (NCI).
\end{abstract}

Design/methodology/approach -One hundred and six questionnaires retrieved from construction professionals in the micro, small, medium, and large enterprises were used to conduct both descriptive and inferential statistics, namely mean score, standard deviation, Kruskal-Wallis $\mathrm{H}$ test, post hoc test, and factor analysis.

Findings - The analyses show that the drivers of EMS implementation in the NCI could be grouped into intellectual enhancement strategies, documentation and cultural strategies, and motivation and tracking strategies. The study concluded that training and education of relevant stakeholders, tracking compliance levels of organisations, and recognising firms acting in compliance with stipulated 'environmental' policy are essential. It was recommended that the collaboration of all construction stakeholders be upheld to aid EMS implementation in the NCI.

Originality/value - This paper investigated the drivers of EMS with the opinions of construction professionals in the mainstream of the NCI through a survey to ensure wide coverage of respondents. Investigating the view of construction professionals in the micro, small, medium, and large enterprises helped determine possible significant differences. Thus, practical implications of the study were also provided in a systematic manner.

Keywords: Construction industry, Drivers, Environmental Management System, Nigeria, Sustainability.

\section{Introduction}

The need to decrease environmental degradation caused by the construction industry has been a topical issue in recent decades (Zhu et al., 2013; Shan et al., 2020). This owes to the adverse effects of different hazardous materials being introduced to the environment via construction activities. For instance, a study revealed that 40 per cent of water pollution and 80 per cent of air pollution could be traced to industrialisation and various construction activities (Wang et al., 2004; Li et al., 2019a; Chuai et al., 2021). Some environmental nuisances such as noise, dust, muddy runoffs, and inappropriate chemical waste disposal caused by construction operations have also been reported (Tse, 2001). Previous research works revealed that the impact of such pollutions on construction workers and the citizens' quality of life is enormous (Zheng et al., 2019; Bodaghpour et al., 2012). Besides, the natural ecosystem also shares the detrimental effect of the toxic substances released to the environment by the construction 
industry (Chen et al., 2020; White, 2007). In addition, construction activities directly impact the safety of construction workers and environmental performance in different countries in which the Nigerian construction industry (NCI) is not exempted.

The negative impacts of the harmful constructions' substances on the environment led to introducing different mitigating strategies. For example, the introduction of manufactured nanomaterials in the execution of construction projects was to offset the concern of environmental contaminants (Lee et al., 2010). The promulgation of Environmental Management System (EMS), which is a coordinated framework to control the environmental impact of an organisation; eco-management and audit system, CSA-Z750-94, BS 7750, and ISO 14000 series amongst others are to promote eco-friendly practices in the industry (de Oliveira Neves et al., 2017; Lira et al., 2021). To this end, developed nations like the US, Germany, Australia, and Japan have implemented management systems to protect their environment (Qian et al., 2018; Ziegler and Rennings, 2004). Meanwhile, developing nations, namely Nigeria, Indian, etc., are yet to fully embrace the necessary shift that preserves the environment (Singh et al., 2015; Kola-Lawal et al., 2014).

With the increasing demand for environmental protection, several prominent and well-known construction organisations across the world have undertaken measures to reduce their environmental impact. However, approach to EMS implementation differ from country to country, and several researchers have examined factors affecting effective implementation of EMS in the construction industry, for instance, in Hong Kong (Liu et al., 2012; Shen and Tam, 2002), Brazil and Slovenia (Campos et al., 2014), Vietnam and Cambodia (Le et al., 2014), Malaysia (Omran and Yahya, 2020), Egypt (Sakr et al., 2010), Portugal (Dominguez et al., 2016) and Nigeria (Owolana and Booth, 2016). To be precise, pro-environmental behaviour in the NCI is uncertain due to the paucity of continuous improvement culture and other impediments (Babalola et al., 2019; Kola-Lawal et al., 2014). Although most scholarly articles documented the benefits of implementing EMS in the construction industry, namely, increased market share, improved reputation, competitiveness, reduction in environmental risks, etc. (Mazzi et al., 2016; Owolana and Booth, 2016; Hoonakker et al., 2010), meanwhile, such testimonies are not available in the NCI in respect to environmental management.

It is worthy to note that previous studies addressed the barriers hindering EMS implementation for environmental sustainability in the NCI (Ojo et al., 2021; Ogunsanya et al., 2019; Owolana and Booth, 2016; Kola-Lawal et al., 2014). Whereas studies on the drivers of EMS in the NCI are scarce. The study of Kola-Lawal et al. (2014) assessed the drivers of EMS implementation in the NCI. Nine percent of the 136 respondents, i.e., 12 construction professionals in their study were from the mainstream of the NCI. The 12 respondents are not a representative of the construction professionals in the study area. Besides, the study did not in particular focus on investigating the drivers of EMS implementation in the NCI. Thus, the need to investigate the drivers of EMS implementation in the NCI becomes imperative. In a recent study (Ojo et al., 2021), the barriers to implementation of EMS in the NCI were investigated. Ojo et al. (2021) further suggested that complementary drivers of EMS implementation in NCI should also be investigated. Against this background, it was thought significant to further investigate relevant drivers of EMS in the context of NCI. Therefore, this study in particular aims to group the drivers of EMS implementation in the NCI into a manageable size for ease of discussion. This is important to proffer suitable recommendations for the environmental performance and competitiveness of the NCI in the global construction market.

In other sections of this paper, a comprehensive literature review was conducted to identify the 
drivers of EMS implementation. A questionnaire was developed with these drivers to elicit the opinions of construction professionals in micro, small, medium, and large enterprises. The research methodology section explicitly described the approach employed to collect the data. Several statistical analyses, namely, mean score, standard deviation (S.D.), Kruskal-Wallis H test, post hoc test, and factor analysis were conducted. The research findings which will contribute to the body of knowledge were discussed. Practical recommendations and conclusions were also drawn from the study.

\section{Literature Review}

\section{Environmental Management System}

Most of the environmental management tools, EMS inclusive, evolved from Environmental Impact Assessment (EIA) concepts and ideas (Sánchez and Hacking, 2002). Several countries that have not embraced EMS adopted EIA to control several industry actions' adverse effects (Li et al., 2019b; Aliyu et al., 2019). In Nigeria, the EIA Act promulgated in 1992, and now Cap. E12 LFN 2004 was enacted to ensure balanced environmental decision-making for public interest (Ewurum et al., 2020). The EIA Act forbids any sector of the economy from undertaking any activities without environment assessment of the impact of the activities (Sodipo et al., 2017; Ewurum et al., 2020). Despite this, the environment continuously faces threats, especially from various construction activities (Ijigah et al., 2013; Aliyu et al., 2019). Besides, several studies revealed the limitations of EIA, which necessitated the adoption of EMS (Corsten et al., 2013; Zhao et al., 2012). EIA is applied at the planning stage of new projects to determine the negative environmental impacts, while EMS considers the planning stage, implementation and operation stage, checking and corrective actions, and management review (Sánchez and Hacking, 2002). The potential impacts of a project are basically considered in EIA through the experience of the professionals involved, while EMS ensures that both potential and actual impacts are considered (Glasson et al., 2012; Sánchez and Hacking 2002). EIA often lacks follow-up actions which makes it difficult to determine the effectiveness of the evaluation of the potential impacts (Petts, 2009; Wood, 2009; Marshall, 2015). Meanwhile, EMS addresses the limitations of EIA, and it is a cost-effective environmental management tool (Matuszak-Flejszman, 2009; Sánchez and Hacking, 2002). Besides, EMS implementation covers a wide spectrum of benefits, namely, care for the environment, improvement of the image of organisations, promoting pro-environmental behaviour among employees, etc. (Matuszak-Flejszman, 2009). Considering the benefits of EMS implementation, it is important to investigate the drivers of its implementation in the construction industry of developing nations.

Environmental management principles can be traced to the first United Nations Conference on Human Environment in 1972 (Fiorini et al., 2018). The World Commission on Environment and Development (WCED) was established; several countries also created environmental departments, ministries, and agencies (WCED, 1987; Emas, 2015). Since then, organisations' environmental responsibilities have attracted debates between scholars and practitioners (Siew, 2015; Dao et al., 2011). To this end, most countries and organisations have introduced new legislation, economic instruments, policies, and management tools such as EMS to encourage environmental sustainability (Vatn, 2015; Demirel and Kesidou, 2011). Thus, EMS implementation has been widely denoted for an organisation's long-term growth, innovation, and competitiveness (Evans et al., 2017; Kniaz et al., 2020).

EMS is defined as a systematic documentation process that helps manage an organisation's 
environmental impact to attain sustainable development and practices (Lo-Iacono-Ferreira et al., 2016). It is also described as a coordinated framework that assists an organisation in complying with environmental regulations and achieving environmental goals (Gunawan et al., 2020). Thus, EMS has been very useful in attaining sustainability and organisational environmental performance (Pechancová et al., 2019; Ikram et al., 2019; Erdas et al., 2015). The four reasons every company should incorporate environmental considerations into its management processes are (1) ethical reason - ethical behaviour towards ensuring sustainability; (2) economic reason - conserving resources and minimising wastage, thereby saving cost; (3) commercial reason - taking control of environmental responsibilities by the contractors, suppliers, and subcontractors; and (4) legal - compliance with legal requirements (Edward, 2003; Oladinrin et al., 2015; Pacana and Ulewicz, 2017; Mas-Machuca and Marimon, 2019; Harris et al., 2021).

EMS implementation involves logical steps of inspiration, decision making, assigning EMS implementation team, assigning auditors and external consultant, training, environmental and management review, system project draft, internal audits, and system certification process (Pacana et al., 2017). Whereas there is a paucity of these logical steps in organisations of developing countries (Kola-Lawal et al., 2014; Singh et al., 2015; Kabir and Khan, 2020). Several environmental problems, namely, deforestation, industrial pollution, etc., persist in developing nations, therefore, the need to investigate the drivers of EMS implementation in the NCI is important (Dkhili, 2018; Hoang et al., 2019; Zhang et al., 2021).

\section{Drivers of Environmental Management System}

Specific drivers could enhance the implementation of EMS. The drivers of EMS implementation can be categorised into external drivers (geared by the government or the society) and internal drivers (by an individual organisation) (Longoni et al., 2018; Zeng et al., 2011; Testa and Iraldo, 2010). The collaboration of these major stakeholders (government and organisations) brings about environmental and economic performance. To be specific, the provision of motivations, recognition, or rewards for organisations promoting proenvironmental behaviour is significant to environmental management practice (Moorthy et al., 2012; Hoffman et al., 2012). Such motivation could also be given to an individual employee who employed "green" ideas in an organisation (Razumova et al., 2015; Mathiyazhagan et al., 2018). Meanwhile, the reward system has been denoted to impact the organisation if the managers recognised implementing eco-friendly practices (Razumova et al., 2015). This reflects the influence a top management official has on the subordinates in an organisation. In a nutshell, recognition and reward for pro-environmental behaviour could encourage other organisations and individuals to follow suit or devise means of better practising environmental activities.

The availability of published policy statements on environmental matters is another enabler of environmental-friendly practices (Patel, 2017; Aktas and Ozorhon, 2015; Studer et al., 2006). This driver underscores the government's efforts to communicate the policy documents that describe eco-friendly practices to all concerned organisations. It is important to note that the government dramatically influences compliance with the document, especially in the construction industry (Lin et al., 2019; Yap et al., 2019). Mazzi et al. (2016) and Chen et al. (2015) posited that strict regulation to ensure compliance must be provided by the government and an appropriate penalty for defaulters. Interestingly, Li et al. (2019a) revealed that the government's effort and the educational knowledge of construction professionals are fundamental to environmental practices in the Chinese construction industry. This is because, 
the availability of a vital policy document does not guarantee compliance with the dictates of the policy (Adeniyi et al., 2020). However, creating public awareness and a sense of social responsibility on the subject matter must precede any policy enforcement (Ikram et al., 2019; Babiak and Trendafilova, 2011). This is corroborated in the submission of Ferdous et al. (2019) that the citizens' expectations regarding environmental performance is important in assisting the efforts of government \& regulatory bodies. This implies that the inputs of the general populace and the government are vital to ensure that organisations adopt environmentalfriendly practices in their daily operations (Qi et al., 2011). In the same vein, a regular EMS audit would also help to assess business organisations' compliance with stipulated directives (Hassan et al., 2019; Breslow, 2015; Ammenberg and Sundin, 2005). According to Opoku et al. (2019), regular EMS audit could be inferred as a specific role for the government; and this can help organisations to be environmentally conscious. Besides, studies revealed that public campaigns and regulations might be ineffective when the top management officer in organisations are not committed to the enacted rule and policy (Hu et al., 2012). This implies that the commitment of government officials must first be firmly secured. Thus, the in-house assurance among top government officers would assist in enforcing the policy in the organisations.

In a bid to ensure environmental management practice, the provision of an in-house training programme is an influential driving factor at the organisational level (Bravi et al., 2020; Jabbour, 2013). Training equips employees on the essence of pro-environmental behaviour and how business practices can be improved to meet recent global expectations (Owolana and Booth, 2016; Agan et al., 2013). It also stimulates individual employees to devise thoughtful means of undertaking expected services in an eco-friendly manner. It is worthy to note that such creativity thrives in an organisation that operates inclusive management in which an employee could exercise a considerable level of power (Al-Dmour et al., 2018). To this end, it could be posited that the availability of training and lifelong learning platforms in organisations requires top management support (Kehbila et al., 2009; Alwan et al., 2017). This could be through provision of necessary facilities and funds for the training with other intangible resources to motivate the employees (Testa et al., 2011; Zutshi and Sohal, 2004). Also, in organisations with continuous improvement culture, the lack of facilities for lifelong learning would not impede embracing innovative methodologies. Meanwhile, Ojo (2018) submitted that the absence of such an improvement culture is a debilitating factor to organisational performance in developing countries. In sum, organisations with functional structures empower their employees, and such establishments perform better amidst their competitors (Al-Dmour et al., 2018; Ololade and Rametse, 2017; Testa et al., 2011). It is also interesting to note that organisations with a desire to operate at international standards are more likely to embrace environmental performance measures than establishments without intention for global competitiveness (Massoud et al., 2010).

Organisational communication is also essential to implement or embrace EMS. According to Lo-Iacono-Ferreira et al. (2018), communication plays a central role in identifying the present position of an organisation in respect to EMS, the promulgation of a policy statement, development of EMS manual, and the implementation and control process. Thus, an organisation must be factual in addressing their fundamental business practices, unanimously brainstorm and develop improvement strategies to attain an enviable height among other organisations. Teamwork from different units of the organisation cannot be undermined in achieving the outcomes of eco-friendly practices (Jabbour, 2015; Muduli et al., 2020). Therefore, the top management, subordinates, and society must embrace environmental management initiatives as a shared effort (Zeng et al., 2011). For organisations with the 
potential environmental impact, dedicated or specific environmental management measures may be designed at organisational level (Griffith and Bhutto, 2008). However, such dedicated environmental measures could only be developed in large organisations with zeal for enhancing their competitive advantage among competitors (Zhang et al., 2009).

Ultimately, the need to enhance competitive advantage, improve reputation, and general management also motivates organisations to embark on environmentally friendly practices (Mazzi et al., 2016; Owolana and Booth, 2016; Studer et al., 2006). It is further proved that expected performance, such as better profit or image, moral and social responsibility also trigger environment-friendly activities in organisations (Hoffman et al., 2012; Agan et al., 2013; Ahmad et al., 2021). This implies that the desire to attain global relevance amongst other competitors could be a driving factor of engaging environmental-friendly practices. In some instances, modification of standard ISO 14001 document to suit an organisational practice or a country's business environment could be required to encourage innovative ideas on EMS implementation strategies (Ammenberg and Sundin, 2005). According to Ammenberg and Sundin (2005), the availability of ISO 14001 documents would assist establishments in channeling their resources in organising training and seeking consultancy services to improve environmental performance. However, the availability of ISO 14001 documents to organisations precedes the domestication of such standards to regulate the practices of organisations (Bravi et al., 2020; Opoku et al., 2019). A summary of the drivers of EMS implementation sourced from different scholarly databases, namely, Web of Science, Scopus, Google scholar, etc. with the use of appropriate search string "environmental management system* and drivers of environmental management system*" is presented in Table 1. Thereafter, the articles obtained were carefully checked to identify the drivers of EMS implementation for the study.

"Table 1" here

\section{Research Methodology}

Conducting empirical research and choosing the best design for a study are vital(Ketchen et al., 2018; Kothari and Garg, 2014). This helps to determine if single or multiple source respondents are suitable for the study's research design (Flynn et al., 2018). Thus, in a study to investigate the drivers of EMS implementation in the NCI, adopting a survey design approach could be considered suitable to have a wide opinion of construction professionals working in the mainstream of the NCI. This implies that the construct of EMS in this study underscores the fact that different construction professions or enterprises could likely have diverse opinions on the subject matter (Flynn et al., 2018; Marczyk et al., 2005). Therefore, the survey design approach was employed in this study to help in obtaining large data collection from the target respondents (Ojo et al., 2020).

Therefore, to investigate the drivers of EMS implementation in the NCI, a questionnaire was designed and administered to construction professionals such as architects, engineers, builders, quantity surveyors, and project managers in Lagos State, Nigeria. These construction professionals were selected because of their indispensable roles and skills to provide a sustainable environment (Shan et al., 2020; Ametepey and Ansah, 2014). The choice of Lagos State was based on the premise that the State remains the nerve of commercial and construction activities in Nigeria (Fagbenle et al., 2011). Besides, many construction companies, primarily their head offices are located in this State, with many construction activities being undertaken throughout the year (Oke and Ogunsemi, 2013). 
The questionnaire contained questions to elicit the respondents' background information and the 12 drivers of EMS implementation in the construction industry sourced from the extant literature. The questions on the drivers were asked on a seven-point Likert-type scale ranging from 1 (strongly disagree) to 7 (strongly agree). The choice of a seven-point Likert scale was based on the premise of its extensive granularity in the respondent's opinions against a fivepoint Likert scale (Finstad, 2010). Two Hundred and Five (205) copies of the designed questionnaires were successfully administered with convenient sampling technique to the construction professionals in the target area. This sampling technique was adopted due to the limited time and resources available for the research. The statistical analyses conducted were mean score, S.D., Kruskal-Wallis test, post hoc test, and factor analysis with the aid of Statistical Package for Social Sciences (SPSS version 25). To determine if parametric or nonparametric test would be appropriate for the dataset, a Shapiro-Wilk normality test was conducted (Olawumi and Chan, 2018; Corder and Foreman, 2014). The results of the ShapiroWilk test revealed that the significant levels (p-values) of the drivers are less than 0.05 , which implies that the data are not normally distributed. Hence, non-parametric tests would be suitable for further analysis of the data in this study. Therefore, Kruskal-Wallis H test, a nonparametric test was conducted to determine the significance difference in the data among different groups of the construction enterprises, and the construction professionals (Lix and Keselman, 2018; Corder and Foreman, 2014). Since a non-parametric data was suitable for this study, there is no need for fulfillment of assumptions such as homogeneity of variance (Ostertagová et al., 2014). Factor analysis of the drivers of EMS implementation in the NCI was also conducted to detect underlying relationships among the drivers. The number of the valid responses received is suitable for conducting factor analysis; making the item to sample size ratio 1:8. This is above the minimum ratio required, i.e., 1:5 for conducting factor analysis (Pallant, 2020). The choice of factor analysis was to group the drivers of EMS implementation into a manageable size that adequately represents the observed variables to facilitate easy discussion and decision making (Babatunde et al., 2018; Reio Jr and Shuck, 2015).

\section{Results}

Out of the 205 copies of the questionnaires that were successfully administered, 110 copies were returned, but 106 were suitable for analysis representing $51.7 \%$ of the questionnaire administered. Four of the returned questionnaires were discarded because it was incompletely filled. Among these respondents, $15.8 \%$ were architects, $11.6 \%$ engineers, 61.1 quantity surveyors, $4.2 \%$ builders, and $7.4 \%$ project managers. More than $50 \%$ of the respondents had more than five years of work experience in the construction industry. Majority of the respondents were professional staff $(75.8 \%)$, division head of department in the organisation $(3.2 \%)$, technical staff $(20 \%)$, and clerical staff $(1.1 \%)$. Concerning the academic qualification of the respondents, $11.6 \%$ had diploma certificates, $67.4 \%$ had bachelor's degrees, $16.8 \%$ had master's degrees, and $4.2 \%$ had doctorate degrees. Also, $37 \%$ of the respondents worked in micro-enterprises, $32 \%$ worked in small enterprises, $20 \%$ in medium enterprises, and $11 \%$ worked in large enterprises. The classification of the enterprises was based on the staff strength in the respondent's organisation following the Small and Medium Enterprises Development Agency of Nigeria (SMEDAN) (Kale, 2019) in which organisations with less than ten staff are classified as "micro enterprises"; 10 to 49 staff are "small enterprises"; 50 to 199 are "medium enterprises", and above 199 staff are "large enterprises".

Table 2 shows the mean values and S.D.s of the drivers of EMS implementation in the NCI based on overall respondents and the four classifications of enterprises. The results of the 
overall mean and S.D. indicates that "Training and education (D1)" had the highest mean value of 6.08, "Teamwork (D2)" ranked second with a mean value of 6.03. "Adapting EMS to Nigerian system (D3)" ranked third, while "Environmental performance tracking (D4)" ranked fourth with mean values of 5.95 and 5.94, respectively. "Recognition \& reward (D12)" is the least ranked driver with a mean value of 5.71. All the drivers could be termed 'significant' based on the submission of Harada et al. (2015) that any factor that scored above three-fifths of the Likert type scale, i.e., a mean value of 4.20 on a 7-point scale can be considered significant. The S.D.s of all the 12 drivers (D1 - D12) in this study are approximately 1.00. This implies minimal dataset variability (Oke and Aghimien, 2018; Ojo and Ogunsemi, 2019).

Table 2 also the mean values and S.D.s of the respondents based on their respective enterprises' classifications, i.e., micro, small, medium, and large enterprises. In the micro-enterprises, the mean value ranges from 5.36 to 5.82; from 5.62 to 6.02 in small enterprises; 5.95 to 6.50 among the medium enterprises; and 5.71 to 6.71 in the large enterprises. Therefore, based on Harada et al. (2012) proposition, all the drivers could be regarded as significant to the four classifications of the respondents.

To determine the significance difference among the respondents in the enterprises, KruskalWallis $\mathrm{H}$ test was conducted. The null hypothesis $\left(\mathrm{H}_{\mathrm{o}}\right)$ of the Kruskal-Wallis $\mathrm{H}$ test states that "there is no significance difference in the opinions of the respondents in the various groups on the same drivers of EMS". The null hypothesis is rejected when the p-value is less than 0.05. Investigating the significance difference in respondents' opinions across the various classifications of construction enterprises is important to have a broad horizon on the subject matter and draw useful recommendations and conclusions. It is interesting to note that only one driver, i.e., "Availability of ISO 14001 document (D11)" was statistically different at 0.002 significant level (refer to Table 2). This implies that the respondents in the four classifications of enterprises had the same views on the remaining 11 drivers of EMS implementation in the NCI.

\section{“Table 2" here}

The drivers' mean scores based on the respondents' professional backgrounds were also computed (see Table 3). The mean score values of the drivers of the architects range from 5.33 to 6.13 , from 5.29 to 6.14 (project managers), 5.59 to 6.05 (quantity surveyors), 5.50 to 6.75 (builders), and 6.00 to 6.73 (engineers). Furthermore, the Kruskal-Wallis H test was also conducted to determine the significance difference between the professions of the respondents, i.e., architects, project managers, quantity surveyors, builders, and engineers. The results of the analysis show that "Environmental performance tracking (D7) is significantly different at 0.047 (see Table 3). Thus, it means that all the professionals have the same opinions on the other eleven drivers of EMS implementation in the NCI.

\section{"Table 3" here}

Based on the Kruskal-Wallis $\mathrm{H}$ test results, it is essential to determine the group that contributes to the significant difference in the driver of EMS implementation, i.e., "Availability of ISO 14001 document (D11)". Therefore, a post hoc test was conducted at $\mathrm{p}<0.05$. Post hoc tests are posteriori tests used to determine the group where the differences occurred among three or more groups (Pallant, 2011; Olawumi and Chan, 2020). Post hoc analysis using pairwise MannWhitney tests and applying Bonferroni adjustment to control for Type 1 errors were undertaken for the drivers where the Kruskal-Wallis test indicated significant differences (Cohen, 1988; 
Bowen et al., 2021). The post hoc test results in Table 4 revealed that the significant difference in "Availability of ISO 14001 document (D11)" occurred between the respondents in micro and medium enterprises at 0.000 significant level. The adjusted significant level of 0.002 was obtained in the statistics based on Bonferroni correction for multiple tests for the pairwise comparison between the micro and medium enterprises.

\section{"Table 4" here}

On the other hand, the Post hoc tests on the "Environmental performance tracking (D7)" indicates that the significance difference occurs between the quantity surveyors and the engineers (see Table 5).

\section{"Table 5" here}

The incongruence on the 'Availability of ISO 14001 documents (D11)' posits the fact that the medium enterprises considered guiding documents to be important in facilitating EMS implementation in comparison with micro-enterprises possibly due to the organisational policy, desire to maintain the best performance, and the need to maintain a good environmental image to competitors and other stakeholders. Besides, the micro-enterprises are still at the survival stage; therefore, due diligence to stipulated EMS guiding documents may not be carefully considered in the organisations. These findings corroborate the submission of Adeniyi et al. (2020) that most of the lower-tier organisations do not comply with stipulated processes written in manuals or other guiding documents. The difference in the opinions of the quantity surveyors and the engineers on the 'Environmental performance tracking (D7)' could be linked to the professional training of the quantity surveyors in ensuring an approximate or precise quantity/calculation on any elements on construction projects. Whereas the engineers often prefer lump quantities, costs, and entities together in a bid to describe an element on construction projects. Therefore, the engineers may not completely subscribe to the need for environmental performance tracking.

\section{Factor Analysis}

According to Shen and Liu (2003), conducting an adequacy test of the dataset is the first step to be considered in factor analysis. Therefore, for sampling adequacy, Kaiser-Mayer-Olkin (KMO) of 0.929 at a significant level of 0.000 was obtained, and this shows that Bartlett's Test of Sphericity for correlation adequacy between the variables was highly significant. According to Table 6, the KMO explained that 92.9 percent of the data gathered were adequate, and thus, it explains the suitability of the collected data. The p-value obtained, which is $<0.05$ at a degree of freedom (df) of 66 and chi-square value of 836.552, implies that all the drivers will be significantly correlated at 5\% level, and therefore, exploratory factor analysis is appropriate.

\section{"Table 6" here}

The drivers of EMS implementation were factor analysed by varimax rotation (eigenvalue - 1 cut off). This is important to establish the principal components that constitute each factor. In this analysis, items with factor loading greater than 0.5 were considered satisfactory (see Table 7). This is necessary to satisfy the requirement to ensure items with similar characteristics were converged (Field, 2005). The reliability of the dataset grouping was also checked with Cronbach's alpha $(\alpha)$ value for internal consistency (Pallant, 2011). The three $\alpha$ values generated were $0.761,0.897$, and 0.712 respectively. These $\alpha$ values are above 0.6 , and thus, 
they can be considered satisfactory (Hair et al., 2010). Table 7 also shows that five drivers (D1, D6, D9, D4, and D5) were grouped into the first component of the factor analysis; four drivers, i.e., D8, D11, D2, and D12 grouped into the second component, while D10, D3, and D7 grouped into the last component.

"Table 7" here

\section{Discussion}

This study aims to identify the grouping of the drivers that can facilitate EMS implementation in the NCI. The result of the factor analysis shows that three major groupings could explain the characterisation of the drivers of EMS implementation in the NCI. Based on the analysis, 'training and education (D1)', 'employee empowerment (D6)', 'top management commitment and support (D9)', 'teamwork (D4)', and 'organisational communication (D5)' were referred to as "Intellectual enhancement strategies"; 'EMS audit (D8)', 'availability of ISO 14001 document (D11)', 'adapting EMS to Nigerian system (D2)', and 'organisational culture (D12)' was termed "Documentation and cultural strategies"; while 'recognition \& reward (D10)', 'efficient organisational structure (D3)', and 'environmental performance tracking (D7)' were named "Motivation and tracking strategies". The names of the factors were based on the researchers' judgment, as this aligns with the submission of Henson and Roberts (2006) that there is no specific scientific procedure to be followed in naming the grouping of items in factor analysis. However, the given names largely represent the items that constitute the factors.

\section{Intellectual Enhancement Strategies}

The five drivers (i.e., D1, D6, D9, D4, and D5) that denote items for describing 'intellectual enhancement strategies' in an organisation were grouped in the analysis. Training and education have the highest factor loading; this implies that educating employees via training and practicums about environmental sustainability is significant to EMS implementation in the NCI. This corroborates a submission that harnessing an organisation's intellectual assets in a community, or country via training is vital for innovative development (Kuznetsova et al., 2017). Employee empowerment (D6) also dovetailed into the factor named intellectual enhancement strategies. Employee empowerment indicates participative or inclusive management in organisations (Al-Dmour et al., 2018). Employee empowerment connotes giving privilege to employees to exercise a level of power to improve organisation performance without consulting a superior for approval before taking such actions. For instance, the consciousness of the environmental impact of an organisation's activities could propel an employee to devise creative and environment-friendly means of discharging an expected duty. Therefore, employee empowerment helps to stimulate creativity and assists in influencing other colleagues in an organisation.

It is worthy to note that top management commitment and support also underscore intellectual enhancement strategies. Training, provision of lifelong learning schemes, and empowerment schemes in organisations can only thrive through the organisation's commitment and support. Thus, top management commitment and support are vital to enhancing EMS implementation in construction organisations. Besides, the knowledge of the benefits of EMS by superiors in an organisation contributes significantly to EMS implementation (Wang et al., 2019; Huang and Shih, 2009). In other parlance, the knowledge acquired through training and empowerment schemes on the need to keep all ecological habitats safe in an organisational domain is pivotal 
to implementing EMS in any business sector.

Teamwork (D4) and organisational communication (D5) also indicate drivers to describe intellectual enhancement strategies in EMS implementation. Teamwork and organisational communications are values and intangible assets that contribute to organisational reputation. Intellectual strategies consist of explicit and tacit knowledge that helps create values, supports, uplifts, and helps achieve organisational goals. To this end, the drivers in this group are intellectual enhancement strategies capable of harnessing EMS implementation in the NCI. This corroborates Li et al's (2019c) findings that intellectual capital hinged on demand and supply of information, formal employee training, and communication \& knowledge sharing at the individual and organisational level.

\section{Documentation and Cultural Strategies}

The drivers that constitute 'documentation and cultural strategies' are EMS audit (D8), availability of ISO document (D11), adapting EMS to Nigeria system (D2), and organisational culture (D12). The availability of guiding documents for EMS implementation is pivotal and critical as it has high factor loading. The availability of ISO documents furnishes organisations with strategies on EMS practices and helps organisations review their current practices to identify actions that are detrimental to the environment (ISO 14001, 2004). The review process indicates an EMS audit to determine how the organisation complies with the stipulated process. Also, the description of EMS highlights formulated policies and objectives which take into account significant environmental impacts through the implementation and fulfilment of the requirements of the ISO document (Campos, 2012). Therefore, the organisations or government's provision of such policies and objectives at the national level in Nigeria could assist in EMS implementation.

The analysis also shows that adapting EMS to the Nigerian system (D2) has high factor loading; this implies that domesticating ISO documents to suit the Nigerian construction environment is vital to EMS implementation. It is worthy to note that the availability of variants of ISO documents such as BS 7750 EMS standard, European Unions' Eco-Management and Audit Scheme Regulations (EMAS) helps in sustainable practice in some developed countries (Haque, 2018). Finally, organisational culture (D12) also indicates a driver to accentuate documentation and cultural strategies. Organisational culture often reflects values that distinguish one organisation from another (Connolly et al., 2017). Thus, it is worthy to note that the compliance of construction organisations to the content of EMS implementation guidelines may differ due to the size and stage of growth of an enterprise. For example, organisations at survival or existence stages may unlikely consider environmental-friendly practices documented in manuals or publications in detail. Therefore, devising strategic means through which organisations could be involved in eco-friendly practices is vital to enhance EMS implementation in the NCI.

\section{Motivation and Tracking Strategies}

The analysis revealed that D10, D3, and D7 represent drivers that hinge on 'motivation and tracking strategies'. It is important to note that recognition and reward (D10) for eco-friendly practices in an organisation could encourage others to do likewise. Also, an efficient structure to ensure continuity of the reward system must be considered as well. This implies that the reward given for environmental compliance must be affordable. Terms and conditions for eligibility in the reward system could be drafted to create checks and balances. Environmental 
performance tracking (D7) also connotes a driver for motivation and tracking strategies in the analysis conducted. Tracking the compliance of organisation concerning environmental management policies could assist in EMS implementation. On the other hand, the knowledge of adverse environmental effects on the environment could also help to hasten EMS implementation in the NCI. Thus, compliance with the stipulated policy is an integral determinant of EMS implementation (Fura, 2013). Therefore, it is important to put in place motivation and tracking mechanisms by the appropriate authority for the enforcement of EMS policy.

Interestingly, previous study revealed three critical impediments to EMS implementation in the NCI, namely 'knowledge barrier', 'process barrier', and 'culture and management barrier' (Ojo et al., 2021). Therefore, to avert these barriers, this study revealed the complementary drivers (intellectual enhancement strategies, documentation and cultural strategies, \& motivation and tracking strategies) that could enhance EMS implementation in the NCI.

\section{Implications of the Study}

The exploratory factor analysis revealed that the drivers of EMS implementation in the NCI could be represented in three factors: intellectual enhancement strategies, documentation and cultural strategies, and motivation and tracking strategies. This study revealed the importance of education to construction professionals in the NCI. Tertiary institutions could spearhead the training and education required to enhance the intellectual capacity of construction professionals through the provision of unique courses/modules that address EMS practices and their usefulness to the construction industry and the environment at large. The professional bodies could also equip their respective member with knowledge on the importance of EMS to organisational performance via webinars, seminars, and workshops. In other words, the tertiary institutions provide intellectual skills to undergraduate and postgraduate students while professional bodies provide lifelong learning practices to other construction professionals that may not need to acquire an academic degree again. The multi-national construction organisations in the NCI could also conduct in-house training for their employees and other construction professionals in the form of corporate social responsibility as a means of giving back to society. The government as well should provide the necessary facilities to aid education and training at all levels. This implies that the implementation of EMS is a unanimous effort of all construction stakeholders.

The study also revealed the importance of top management commitment and support in enhancing EMS implementation in the NCI. This implies a great responsibility on the part of top management officials in construction organisations, legislative bodies, and the government. It is important to note that the commitment and support of top management officials lie in the knowledge they possess on the impact of various construction activities on the ecosystem at large. Therefore, it is recommended that top management officials at all levels possess environmental management certification. The foreknowledge on environmental issues by top management would assist in establishing support schemes to enable organisations' employees acquire similar training and education. It is also important that top management officials attend international conferences regularly to familiarise themselves with recent developments in the global construction industry. Besides, a substantial amount of money should be set aside in organisations for subscriptions to scholarly articles updates necessary to improve environmental performance in the construction industry.

Documentation of the EMS practices of every organisation is also important to have a review 
process as revealed in the study. The documentation of eco-friendly practices could be the responsibility of either government or the respective organisation. In other words, each construction organisation could keep this record for future assessment of sustainable practices of their organisations. The government could also keep the record of EMS practices and compliance of construction organisations at the national, regional, or local level. This documentation would help to know how to review the country's response to EMS policy and determine the kind of training, conferences, and seminars that may be organised at all levels for construction professionals. The documentation would also help to determine the kind of support for an organisation and how EMS implementation can be tracked on a project, organisational, social, and environmental outcomes. Therefore, it is recommended that every construction organisation set up a department to ensure documentation and environmental compliance tracking. The government could also establish an environmental enforcement agency purposely to oversee the activities of the construction industry concerning environmental matters.

\section{Limitations and Future Research}

Generalizability of the findings of this study is limited by certain factors. First, a major percentage of the respondents were quantity surveyors which may constitute a level of biasness, possibly due to the convenience sampling adopted in the study. There is every possibility that different results may be generated if data were retrieved from other categories of respondents in approximate or similar quantities. Secondly, the findings of this study are applicable to other developing countries with slow implementation of EMS in their construction enterprises. Lastly, the drivers of EMS implementation were gathered from the existing literature and measured by respondents' opinions. While this is considered suitable, it may not capture the drivers of EMS in entirety. This implies that a qualitative study would be important to identify other drivers that could facilitate EMS implementation in the NCI. However, this study achieved its aim through the various statistical analyses conducted.

\section{Conclusions}

The impacts of different construction activities on the quality of life of construction professionals and the ecosystem have been receiving scholarly attention. Considering the importance of EMS implementation, one would expect all construction industries should swiftly embrace it. However, the situations in developing countries appeared not to project the efforts of developed countries and sustainability-concerned organisations to promote sustainable construction practices. This study, therefore, investigated the drivers of EMS implementation in the NCI, intending to group them into a manageable size. The opinions of 106 respondents were used in this study, using both descriptive and inferential statistics. The results of the factor analysis revealed that EMS implementation drivers could be described as intellectual enhancement strategies, documentation and cultural strategies, and motivation and tracking strategies. Each driver that formed the factors has significant factor loading, and the respective $\alpha$ values are also satisfactory. Conclusively, the three 'critical factors' that depict knowledge enhancement, documentation strategies, and motivation with tracking strategies could be described as complementary drivers of EMS implementation in the NCI that could address the barriers to its implementation.

The study revealed the need to synergise relationships between the government and construction organisations to ensure EMS implementation in the NCI. Training and education on environmental practices were recommended for construction professionals. Government 
should also keep proper documentation of EMS-related policies and check compliance of organisations with environmentally friendly construction practices. In collaboration with multinational construction organisations, professional organisations could organise conferences and seminars that would help improve the knowledge of EMS and strategies for its implementation. While the results of the analyses conducted in this study are valid and reliable in this context, it would be good to establish further the grouping of the drivers of EMS implementation in the NCI with structural equation modelling (SEM) to have a better prediction (Tarka, 2018). This also implies that a larger sample size beyond that of this study would be required.

However, this study provides answers to the complementary drivers to ease the barriers to EMS implementation in the NCI. The construction professional bodies would also benefit from this study by understanding the areas of improvement for the construction practitioners. Lastly, the government organisations could also use the outcomes of this study to determine the areas to concentrate efforts on to ensure pro-environmental behaviour for improving the image of the $\mathrm{NCI}$ in the global market.

\section{References}

Adeniyi, O., Ojo, L. D., Idowu, O. A., and Kolawole, S. B. (2020), "Compliance with the stipulated procurement process in local governments: A case from a developing nation", International Journal of Procurement Management, Vol. 13 No. 5, pp. 678-700.

Agan, Y., Acar, M. F., and Borodin, A. (2013), "Drivers of environmental processes and their impact on performance: a study of Turkish SMEs", Journal of Cleaner Production, Vol. 51, pp. 23-33.

Ahmad, N., Ullah, Z., Arshad, M. Z., waqas Kamran, H., Scholz, M., and Han, H. (2021), "Relationship between corporate social responsibility at the micro-level and environmental performance: The mediating role of employee pro-environmental behavior and the moderating role of gender", Sustainable Production and Consumption, Vol. 27, pp. $1138-1148$.

Aktas, B., and Ozorhon, B. (2015), "Green building certification process of existing buildings in developing countries: cases from Turkey", Journal of Management in Engineering, Vol. 31 No. 6, pp. 05015002.

Al-Dmour, R., Yassine, O., and Masa'deh, R. (2018), "A review of literature on the association among employee empowerment, work engagement and employee performance", Modern Applied Science, Vol. 12 No. 11, pp. 313-329.

Aliyu, B. S., Fareed, M. M. Z., Nazifi, S. H. J., Bello, D. Y., and Auwalu, B. A. (2019), "Impact of construction practices on the environment: A case study of Kano State, Nigeria", Bayero Journal of Pure and Applied Sciences, Vol. 12 No. 1, pp. 18-23.

Alwan, Z., Jones, P., and Holgate, P. (2017), "Strategic sustainable development in the U.K. construction industry, through the framework for strategic sustainable development, using Building Information Modelling", Journal of Cleaner Production, Vol. 140, pp. 349-358.

Ametepey, S. O., and Ansah, S. K. (2014), "Impacts of construction activities on the environment: the case of Ghana", Journal of Construction Project Management and Innovation, Vol. 4 No. 1, pp. 934-948.

Ammenberg, J., and Sundin, E. (2005), "Products in environmental management systems: drivers, barriers and experiences", Journal of Cleaner Production, Vol. 13 No. 4, pp. 405415.

Babalola, O., Ibem, E. O., and Ezema, I. C. (2019), "Implementation of lean practices in the construction industry: A systematic review”, Building and Environment, Vol. 148, pp. 3443 . 
Babatunde, S. O., Awodele, O. A., and Adeniyi, O. (2018), "Opportunities and challenges of foreign direct investment utilisation and its impact on the construction sector in developing countries", Journal of Financial Management of Property and Construction, Vol. 23 No. 2, pp. 239-256.

Babiak, K., and Trendafilova, S. (2011), "CSR and environmental responsibility: motives and pressures to adopt green management practices", Corporate Social Responsibility and Environmental Management, Vol. 18 No. 1, pp. 11-24.

Bodaghpour, S., Joo, N. B., and Ahmadi, S. (2012), "A review on the existence of chrome in cement and environmental remedies to control its effects", International Journal of Geology, Vol. 2 No. 6, pp. 62-67.

Bowen, P., Zhang, R. P., and Edwards, P. (2021), "An investigation of work-related strain effects and coping mechanisms among South African construction professionals", Construction Management and Economics, Vol. 39 No. 4, pp. 298-322.

Bravi, L., Santos, G., Pagano, A., and Murmura, F. (2020), "Environmental management system according to ISO 14001: 2015 as a driver to sustainable development", Corporate Social Responsibility and Environmental Management, Vol. 27 No. 6, pp. 2599-2614.

Breslow, S. J. (2015), "Accounting for neoliberalism: "Social drivers" in environmental management", Marine Policy, Vol. 61, pp. 420-429.

Campos, L. M. (2012), "Environmental management systems (EMS) for small companies: A study in Southern Brazil" Journal of Cleaner Production, Vol. 32, pp. 141-148.

Campos, L. M., Trierweiller, A. C., Spenassato, D. C., Bornia, A. C., and Šelih, J. (2014), "Barriers for Implementation of EMS: A study in the Construction Industry of Brazil and Slovenia", Proceedings of Production and Operations Management Society 25th Annual Conference, pp. 1-10.

Chen, H., Tang, L., Qiu, Q., Hou, L., and Wang, B. (2020), “Construction and case analysis of an index for the sustainability of ecosystem services", Ecological Indicators, Vol. 115, pp. 106370.

Chen, L., Tang, O., and Feldmann, A. (2015), “Applying GRI reports for the investigation of environmental management practices and company performance in Sweden, China, and India", Journal of Cleaner Production, Vol. 98, pp. 36-46.

Chuai, X., Lu, Q., Huang, X., Gao, R., and Zhao, R. (2021), "China's construction industrylinked economy-resources-environment flow in international trade", Journal of Cleaner Production, Vol. 278, pp. 123990.

Cohen, J. (1988). Statistical power analysis for the behavioural science, (2 ${ }^{\text {nd }}$ ed.) Hillsdale, NJ: Lawrence Erlbaum Associates.

Connolly, L. Y., Lang, M., Gathegi, J., and Tygar, D. J. (2017), “Organisational culture, procedural countermeasures, and employee security behaviour", Information \& Computer Security, Vol. 25 No. 2, pp. 118-136.

Corder, G. W., and Foreman, D. I. (2014), Non-parametric statistics: A step-by-step approach. Hoboken, NJ: Wiley.

Corsten, M., Ramírez, A., Shen, L., Koornneef, J., and Faaij, A. (2013), "Environmental impact assessment of CCS chains-lessons learned and limitations from LCA literature", International Journal of Greenhouse Gas Control, Vol. 13, pp. 59-71.

Dao, V., Langella, I., and Carbo, J. (2011), "From green to sustainability: Information Technology and an integrated sustainability framework", The Journal of Strategic Information Systems, Vol. 20 No. 1, pp. 63-79.

de Oliveira Neves, F., Salgado, E. G., and Beijo, L. A. (2017), “Analysis of the Environmental Management System based on ISO 14001 on the American continent", Journal of Environmental Management, Vol. 199, pp. 251-262.

Demirel, P., and Kesidou, E. (2011), "Stimulating different types of eco-innovation in the U.K.: 
Government policies and firm motivations", Ecological Economics, Vol. 70 No. 8, pp. 1546-1557.

Dkhili, H. (2018), "Environmental performance and institution quality: Evidence from developed and developing countries", Marketing and Management of Innovation, Vol. 3, pp. 333-344.

Dominguez, C., Felgueiras, J., and Varajão, J. (2016), "Environmental management systems certification: insights from Portuguese construction companies", Environmental Engineering \& Management Journal, Vol. 15 No. 11, pp. 2383-2394.

Durdyev, S., Zavadskas, E. K., Thurnell, D., Banaitis, A., and Ihtiyar, A. (2018), "Sustainable construction industry in Cambodia: Awareness, drivers and barriers", Sustainability, Vol. 10 No. 2, pp. 1-19.

Edwards, A. J. (2003), ISO 14001 Environmental Certification Step by Step: Revised Edition. Elsevier.

Emas, R. (2015), "The concept of sustainable development: definition and defining principles", 2015 Brieffor GSDR, pp. 1-3.

Erdas, C., Fokaides, P. A., and Charalambous, C. (2015), "Ecological footprint analysis based awareness creation for energy efficiency and climate change mitigation measures enhancing the environmental management system of Limassol port", Journal of Cleaner Production, Vol. 108, pp. 716-724.

Evans, S., Vladimirova, D., Holgado, M., Van Fossen, K., Yang, M., Silva, E. A., and Barlow, C. Y. (2017), "Business model innovation for sustainability: Towards a unified perspective for creation of sustainable business models", Business Strategy and the Environment, Vol 26 No. 5, pp. 597-608.

Ewurum, N. I., Anih, P. C., and Ifeanacho, K. P. (2020), "Sustainable development through green-themed environmental impact assessment: Lessons for developing countries", Sustainable Development, Vol. 10 No. 5, pp. 64-72.

Fagbenle, O. I., Makinde, F. A., and Oluwunmi, A. O. (2011), "Factors influencing construction clients'/contractors' choice of subcontractors in Nigeria", Journal of Sustainable Development, Vol. 4 No. 2, pp. 254-259.

Ferdous, M. I., Adams, C. A., and Boyce, G. (2019), "Institutional drivers of environmental management accounting adoption in public sector water organisations", Accounting, Auditing \& Accountability Journal, Vol. 32 No. 4, pp. 984-1012.

Field, A. (2005), Discovering statistics using SPSS. Sage Publications, London.

Finstad, K. (2010), "Response interpolation and scale sensitivity: Evidence against 5-point scales", Journal of Usability Studies, Vol. 5 No. 3, pp. 104-110.

Fiorini, P. D. C., Jabbour, C. J. C., de Sousa Jabbour, A. B. L., Stefanelli, N. O., and Fernando, Y. (2019), "Interplay between information systems and environmental management in ISO 14001-certified companies", Management Decision, Vol. 57 No. 8, pp. 1883-1901.

Flynn, B., Pagell, M., and Fugate, B. (2018), "Survey research design in supply chain management: the need for evolution in our expectations", Journal of Supply Chain Management, Vol. 54 No. 1, pp. 1-15.

Fura, B. (2013), “Improving ISO 14001 environmental management systems”, Polish Journal of Environmental Studies, Vol. 22, No. 6, pp. 1711-1721.

Glasson, J., Therivel, R., and Chadwick, A. (2012), Introduction to environmental impact assessment, $4^{\text {th }}$ edition, Routledge, Abingdon.

Griffith, A., and Bhutto, K. (2008), "Improving environmental performance through integrated management systems (IMS) in the UK", Management of Environmental Quality: An International Journal, Vol. 19 No. 5, pp.565-578.

Gunawan, M., Asyahira, R., and Sidjabat, F. M. (2020), "Environmental Management System Implementation in MSMEs: A Literature Review", Jurnal Serambi Engineering, Vol. 5 
No. 2, pp. 1070-1078.

Hair, J. F., Black, W. C., Babin, B. J., and Anderson, R. E. (2010), Multivariate data analysis, ( $7^{\text {th }}$ ed.), Prentice-Hall, NJ.

Haque, M. (2018), An investigation of the effects of home country institutional profile on the adoption of ISO 14001 standard by MNC subsidiaries in Hong Kong, An Unpublished Ph.D. Thesis, University of Sussex, United Kingdom.

Harada, T., Abe, T., Kato, F., Matsumoto, R., Fujita, H., Murai, S., Miyajima, N., Tsuchiya, K., Maruyama, S., Kudo, K., and Shinohara, N. (2015), "Five-point Likert scaling on MRI predicts clinically significant prostate carcinoma", BMC Urology. Vol. 15 No. 1, pp. 1-7.

Harris, F., McCaffer, R., Baldwin, A., and Edum-Fotwe, F. (2021), Modern construction management ( $8^{\text {th }}$ ed.), John Wiley \& Sons: United Kingdom.

Hassan, N. A., Zailani, S. H. M., and Hasan, H. A. (2019), "Integrated internal audit in management system", The TQM Journal, Vol. 32 No. 1, pp. 110-126.

Hoang, T. C., Black, M. C., Knuteson, S. L., and Roberts, A. P. (2019), "Environmental pollution, management, and sustainable development: Strategies for Vietnam and other developing countries", Environmental Management, Vol. 63, pp. 433-436.

Hofmann, K. H., Theyel, G., and Wood, C. H. (2012), "Identifying firm capabilities as drivers of environmental management and sustainability practices-evidence from small and medium-sized manufacturers", Business Strategy and the Environment, Vol. 21 No. 8, pp. 530-545.

Hoonakker, P., Carayon, P., and Loushine, T. (2010), "Barriers and benefits of quality management in the construction industry: An empirical study", Total Quality Management, Vol. 21 No. 9, pp. 953-969.

Hu, Q., Dinev, T., Hart, P., and Cooke, D. (2012), "Managing employee compliance with information security policies: The critical role of top management and organisational culture", Decision Sciences, Vol. 43 No. 4, pp. 615-660.

Huang, P. S., and Shih, L. H. (2009), "Effective environmental management through environmental knowledge management", International Journal of Environmental Science \& Technology, Vol. 6 No. 1, pp. 35-50.

Ijigah, E. A., Jimoh, R. A., Aruleba, B. O., and Ade, A. B. (2013), "An assessment of environmental impacts of building construction projects", Civil and Environmental Research, Vol. 3 No. 1, pp. 93-105.

Ikram, M., Zhou, P., Shah, S. A. A., and Liu, G. Q. (2019), "Do environmental management systems help improve corporate sustainable development? Evidence from manufacturing companies in Pakistan", Journal of Cleaner Production, Vol. 226, pp. 628-641.

ISO 14001 (2004), Environmental management system: Requirements with guidance for use. International Organization for Standardization.

Jabbour, C. J. C. (2013), "Environmental training in organisations: From a literature review to a framework for future research", Resources, Conservation and Recycling, Vol. 74, pp. 144-155.

Kabir, Z., and Khan, I. (2020), "Environmental impact assessment of waste to energy projects in developing countries: General guidelines in the context of Bangladesh", Sustainable Energy Technologies and Assessments, Vol. 37, pp. 100619.

Kale, Y. (2019), Micro, small, and medium enterprises (MSME) national survey 2017 report. Presentation of Statistician-General of the Federation/CEO National Bureau of Statistics, Abuja, Nigeria.

Kehbila, A. G., Ertel, J., and Brent, A. C. (2009), "Strategic corporate environmental management within the South African automotive industry: motivations, benefits, hurdles", Corporate Social Responsibility and Environmental Management, Vol. 16 No. 6 , pp. 310-323. 
Ketchen Jr, D. J., Craighead, C. W., and Cheng, L. (2018), "Achieving research design excellence through the pursuit of perfection: Toward strong theoretical calibration", Journal of Supply Chain Management, Vol. 54 No. 1, pp. 16-22.

Kniaz, S., Zaiats, O., Shayda, O., Danko, T., Baidala, N., Merezhko, N., ... and Holovina, O. (2020), "Development of environmental management system by industrial enterprises", ARCTIC, Vol. 73 No. 3, pp. 56-69.

Kola-Lawal, C., Wood, M., Alo, B., and Clark, A., (2014), "Factors in organisational environmental management system implementation-developed vs. developing country contexts", Journal of Sustainable Development of Energy, Water and Environment Systems, Vol. 2 No. 4, pp. 408-421.

Kothari, C.R., and Garg, G (2014), Research methodology: Methods and techniques, (3 $\left.{ }^{\text {rd }} \mathrm{Ed}.\right)$ New Age, New Delhi.

Krause, D., Luzzini, D., and Lawson, B. (2018), "Building the case for a single key informant in supply chain management survey research", Journal of Supply Chain Management, Vol. 54 No. 1, pp. 42-50.

Kuznetsova, O., Kuznetsova, S., Yumaev, E., Kuznetsov, V., and Galtseva, O. (2017), "Formation and Development of the training system for innovative development of regional industry", Proceedings of E3S Web of Conferences on Innovative Mining Symposium, pp. 1-5.

Le, X. Q., Vu, V. H., Hens, L., and Van Heur, B. (2014), "Stakeholder perceptions and involvement in the implementation of EMS in ports in Vietnam and Cambodia", Journal of Cleaner Production, Vol. 64, pp. 173-193.Lee, J., Mahendra, S., and Alvarez, P. J. (2010), "Nanomaterials in the construction industry: a review of their applications and environmental health and safety considerations", ACS Nano, Vol. 4 No. 7, pp. 3580-3590.

Li, C. Z., Zhao, Y., and Xu, X. (2019a), "Investigation of dust exposure and control practices in the construction industry: implications for cleaner production", Journal of Cleaner Production, Vol. 227, pp. 810-824.

Li, H., Deng, Q., Zhang, J., Olanipekun, A. O., and Lyu, S. (2019b), "Environmental impact assessment of transportation infrastructure in the life cycle: Case study of a fast track transportation project in China", Energies, Vol. 12 No. 6, pp. 1-15.

Li, Y., Song, Y., Wang, J., and Li, C. (2019c), "Intellectual capital, knowledge sharing, and innovation performance: Evidence from the Chinese construction industry", Sustainability, Vol. 11 No. 9, pp. 1-20.

Lin, X., McKenna, B., Ho, C. M., and Shen, G. Q. (2019), "Stakeholders' influence strategies on social responsibility implementation in construction projects", Journal of Cleaner Production, Vol. 235, pp. 348-358.

Lira, J. M. S., Salgado, E. G., Beijo, L. A., and Da Silva, C. E. S. (2021), "Shedding light on the diffusion of ISO 14001 across Africa, Asia and Oceania", Journal of Cleaner Production, Vol. 289, pp. 125724.

Liu, A. M., Lau, W. S., and Fellows, R. (2012), "The contributions of environmental management systems towards project outcome: Case studies in Hong Kong", Architectural Engineering and Design Management, Vol. 8 No. 3, pp. 160-169.

Lix, L. M., and Keselman, H. J. (2018), "Analysis of variance: Repeated-measures designs", In Hancock, G. R., Stapleton, L.M. and Mueller, R. O. (eds), The reviewer's guide to quantitative methods in the social sciences, Routledge, Taylor \& Francis Group, pp. 1528.

Lo-Iacono-Ferreira, V. G., Capuz-Rizo, S. F., and Torregrosa-López, J. I. (2018), “Key Performance Indicators to optimise the environmental performance of Higher Education Institutions with environmental management system-A case study of Universitat Politècnica de València", Journal of Cleaner Production, Vol. 178, pp. 846-865. 
Lo-Iacono-Ferreira, V. G., Torregrosa-López, J. I., and Capuz-Rizo, S. F. (2016), "Use of life cycle assessment methodology in the analysis of ecological footprint assessment results to evaluate the environmental performance of universities", Journal of Cleaner Production, Vol. 133, pp. 43-53.

Longoni, A., Luzzini, D., and Guerci, M. (2018), "Deploying environmental management across functions: the relationship between green human resource management and green supply chain management", Journal of Business Ethics, Vol. 151 No. 4, pp. 1081-1095.

Marczyk, G., DeMatteo, D., and Festinger, D. (2005), Essentials of research design and methodology, John Wiley \& sons, inc.

Marshall, R. (2005), "Environmental impact assessment follow-up and its benefits for industry", Impact Assessment and Project Appraisal, Vol. 23 No. 3, pp. 191-196.

Mas-Machuca, M., and Marimon, F. (2019), "Still implementing ISO 14000 for the same reasons?", International Journal for Quality Research, Vol. 13 No. 1, pp. 115-130.

Massoud, M. A., Fayad, R., Kamleh, R., and El-Fadel, M. (2010), "Environmental management system (ISO 14001) certification in developing countries: challenges and implementation strategies", Environmental Science \& Technology, Vol. 44, pp. 1884-1887.

Mathiyazhagan, K., Datta, U., Singla, A., and Krishnamoorthi, S. (2018), "Identification and prioritisation of motivational factors for the green supply chain management adoption: case from Indian construction industries", Research, Vol. 55 No. 1, pp. 202-219.

Matuszak-Flejszman, A. (2009), "Benefits of Environmental Management System in Polish Companies Compliant with ISO 14001", Polish Journal of Environmental Studies, Vol. 18 No. 3, pp. 411-419.

Mazzi, A., Toniolo, S., Mason, M., Aguiari, F., and Scipioni, A. (2016), "What are the benefits and difficulties in adopting an environmental management system? The opinion of Italian organisations", Journal of Cleaner Production, Vol. 139, pp. 873-885.

Moorthy, M. K., Peter, A., Yacob, L., Kumar, M., Chelliah, L., and Arokiasamy, L. (2012), "Drivers for Malaysian SMEs to go green", International Journal of Academic Research in Business and Social Sciences, Vol. 2 No. 9, pp. 74-86.

Muduli, K. K., Luthra, S., Kumar Mangla, S., Jabbour, C. J. C., Aich, S., and de Guimarães, J. C. F. (2020), "Environmental management and the "soft side" of organisations: Discovering the most relevant behavioural factors in green supply chains", Business Strategy and the Environment, Vol. 29 No. 4, pp. 1647-1665.

Ogunsanya, O. A., Aigbavboa, C. O., Thwala, D. W., and Edwards, D. J. (2019), "Barriers to sustainable procurement in the Nigerian construction industry: an exploratory factor analysis", International Journal of Construction Management, pp. 1-12.

Ojo, L. D. (2018), Development of a framework for the adoption of value management in the Nigerian construction industry, An Unpublished Master Thesis of Department of Quantity Surveying, Federal University of Technology, Akure, Nigeria.

Ojo, L. D., Oladinrin, T. O., and Obi, L. (2021), "Critical barriers to environmental management system implementation in the Nigerian construction industry", Environmental Management, Vol. 68 No. 2, pp. 147-159. https://doi.org/10.1007/s00267021-01473-y.

Ojo, L.D, Ibrahim, B., Oke, A., and Akindeinde, A. (2020), "Mitigating strategies of threats to quantity surveying profession in the Nigerian construction industry", Journal of Construction Project Management and Innovation, Vol. 10 No. 2, pp. 1-13.

Ojo, L.D., and Ogunsemi, D.R. (2019), "Critical drivers (CDs) of value management adoption in the Nigerian construction industry: A Delphi study", Journal of Engineering, Design and Technology, Vol. 17 No. 1, pp. 250-264.

Oke, A. E., and Ogunsemi, D. R. (2013), "Key competencies of value managers in Lagos state, Nigeria", Proceedings of 5th West Africa Built Environment Research Conference, pp. 773- 
778.

Oladinrin, T. O., Ho, C. M. F. and Chiang, Y.H. (2015), "Evaluating codes of ethics implementation for a sustainable construction organisation", The First International Conference for Sustainable Development and Management (ICSDM, 28-30 June 2015, Hong Kong).

Olawumi, T. O., and Chan, D. W. (2018), Identifying and prioritising the benefits of integrating BIM and sustainability practices in construction projects: a Delphi survey of international experts, Sustainable Cities and Society, Vol. 40, pp. 16-27.

Olawumi, T. O., and Chan, D. W. (2020), "Concomitant impediments to the implementation of smart sustainable practices in the built environment", Sustainable Production and Consumption, Vol. 21, pp. 239-251.

Ololade, O. O., and Rametse, P. P. (2018), "Determining factors that enable managers to implement an environmental management system for sustainable construction: A case study in Johannesburg", Business Strategy and the Environment, Vol. 27 No. 8, pp. 17201732.

Omran, A., and Yahya, S. H. S. (2020), "Environmental Management System (EMS) within Construction Site: A case study in Kelantan State, Malaysia", Proceedings of IOP Conference Series: Materials Science and Engineering, Vol. 847, No. 1, pp. 012039.

Opoku, D. G. J., Agyekum, K., and Ayarkwa, J. (2019), "Drivers of environmental sustainability of construction projects: a thematic analysis of verbatim comments from built environment consultants", International Journal of Construction Management, pp. $1-9$.

Ostertagová, E., Ostertag, O., and Kováĉ, J. (2014), "Methodology and application of the Kruskal-Wallis test", Applied Mechanics and Materials, Vol. 611, pp. 115-120.

Owolana, V. O., and Booth, C. A. (2016), "Stakeholder perceptions of the benefits and barriers of implementing environmental management systems in the Nigerian construction industry", Journal of Environmental Engineering and Landscape Management, Vol. 24 No. 2, pp. 79-89.

Pacana, A., and Ulewicz, R. (2017), "Research of determinants motiving to implement the environmental management system”, Polish Journal of Management Studies, Vol. 16 No. 1, pp. 165-174.

Pacana, A., Lew, G., and Kulpa, W. (2017), "Rating the quality of implementation of environmental management systems", Journal of Business \& Retail Management Research, Vol. 11 No. 2, pp. 165-169.

Pallant, J. (2011), SPSS survival manual: A step by step guide to data analysis using SPSS (4 ${ }^{\text {th }}$ ed.). Everbest Printing Company. Guangzhou.

Pallant, J. (2020), SPSS survival manual: A step by step guide to data analysis using IBM SPSS ( $7^{\text {th }}$ ed.). New York, USA: Routledge.

Patel, S. H. (2017), Environmental audit impact and applications in India. An Unpublished Ph.D. Thesis, The Maharaja Sayajirao University of Baroda, India.

Pechancová, V., Hrbáčková, L., Dvorský, J., Chromjaková, F., and Stojanović, A. (2019), "Environmental management systems: an effective tool of corporate sustainability", Entrepreneurship and Sustainability Issues, Vol. 7 No. 2, pp. 825-841.

Petts, J. (2009), Introduction to environmental impact assessment in practice: Fulfilled potentials or wasted opportunity? In Petts J. (ed.) Handbook of Environmental Impact Assessment: Volume 2: Impact and Limitations, Blackwell Science Ltd, USA, pp. 3-9.

Qi, G. Y., Zeng, S. X., Tam, C. M., Yin, H. T., Wu, J. F., and Dai, Z. H. (2011), "Diffusion of ISO 14001 environmental management systems in China: rethinking on stakeholders' roles", Journal of Cleaner Production, Vol. 19 No. 11, pp. 1250-1256.

Qian, W., Hörisch, J., and Schaltegger, S. (2018), "Environmental management accounting and 
its effects on carbon management and disclosure quality", Journal of Cleaner Production, Vol. 174, pp. 1608-1619.

Razumova, M., Ibáñez, J. L., and Palmer, J. R. M. (2015), “Drivers of environmental innovation in Majorcan hotels", Journal of Sustainable Tourism, Vol. 23 No.10, pp. 15291549 .

Reio Jr, T. G., and Shuck, B. (2015). Exploratory factor analysis: implications for theory, research, and practice. Advances in Developing Human Resources, Vol. 17 No. 1, pp. 12 25.

Sakr, D. A., Sherif, A., and El-Haggar, S. M. (2010), "Environmental management systems"” awareness: an investigation of top 50 contractors in Egypt", Journal of cleaner production, Vol. 18 No. 3, pp. 210-218.

Sánchez, L. E., and Hacking, T. (2002), “An approach to linking environmental impact assessment and environmental management systems", Impact Assessment and Project Appraisal, Vol. 20 No. 1, pp. 25-38.

Shan, M., Liu, W. Q., Hwang, B. G., and Lye, J. M. (2020), “Critical success factors for small contractors to conduct green building construction projects in Singapore: Identification and comparison with large contractors", Environmental Science and Pollution Research, Vol. 27No. 8, pp. 8310-8322.

Shen, L. Y., and Tam, V. W. (2002), "Implementation of environmental management in the Hong Kong construction industry”, International Journal of Project Management, Vol. 20 No. 7, pp. 535-543.

Shen, Q., and Liu, G. (2003), "Critical success factor for value management studies in construction", Journal of Construction Engineering and Management, Vol. 129 No. 5, pp. 485-498.

Siew, R. Y. (2015), “A review of corporate sustainability reporting tools (SRTs)", Journal of Environmental Management, Vol. 164, pp. 180-195.

Singh, N., Jain, S., and Sharma, P. (2015), "Motivations for implementing environmental management practices in Indian industries", Ecological Economics, Vol. 109, pp. 1-8.

Sodipo, E., Omofuma, O. I., and Nwachi, V. C. (2017), "Environmental law and practice in Nigeria: Overview", Practical Law Country $Q \& A$, pp. 1-24.

Studer, S., Welford, R., and Hills, P. (2006), "Engaging Hong Kong businesses in environmental change: Drivers and barriers", Business Strategy and the Environment, Vol. 15 No.6, pp. 416-431.

Tarka, P. (2018), "An overview of structural equation modeling: its beginnings, historical development, usefulness and controversies in the social sciences", Quality \& quantity, Vol. 52 No.1, pp. 313-354.

Testa, F., and Iraldo, F. (2010), "Shadows and lights of green supply chain management: Determinants and effects of these practices based on a multi-national study", Journal of Cleaner Production, Vol. 18 No. 10/11, pp. 953-962.

Testa, F., Iraldo, F., and Frey, M. (2011), “The effect of environmental regulation on firms' competitive performance: The case of the building \& construction sector in some E.U. regions", Journal of Environmental Management, Vol. 92 No. 9, pp. 2136-2144.

Tse, R. Y. (2001), "The implementation of EMS in construction firms: case study in Hong Kong", Journal of Environmental Assessment Policy and Management, Vol. 3 No. 2, pp. 177-194.

Vatn, A. (2015), Environmental governance: institutions, policies and actions. Edward Elgar Publishing.

Wang, H., Bi, J., Wheeler, D., Wang, J., Cao, D., Lu, G., and Wang, Y. (2004), “Environmental performance rating and disclosure: China's GreenWatch program", Journal of Environmental Management, Vol. 71 No. 2, pp. 123-133. 
Wang, S., Wang, H., and Wang, J. (2019), "Exploring the effects of institutional pressures on implementing environmental management accounting: Do top management support and perceived benefit work?", Business Strategy and the Environment, Vol. 28 No. 1, pp. 233243.

WCED, S. W. S. (1987), "World commission on environment and development", Our common future, Vol. 17 No. 1, pp. 1-91.

White, R. (2007), "Green criminology and the pursuit of social and ecological justice", Issues in Green Criminology, pp. 32-54.

Wood, C. (2009), Comparative evaluation of environmental impact assessment systems. In Petts J. (ed.) Handbook of Environmental Impact Assessment: Volume 2: Impact and Limitations, Blackwell Science Ltd, USA, pp. 10-34.

Yap, J. B. H., Chow, I. N., and Shavarebi, K. (2019), "Criticality of construction industry problems in developing countries: Analysing Malaysian projects", Journal of Management in Engineering, Vol. 35 No. 5, pp. 04019020.

Zeng, S. X., Meng, X. H., Zeng, R. C., Tam, C. M., Tam, V. W., and Jin, T. (2011), “How environmental management driving forces affect the environmental and economic performance of SMEs: a study in the Northern China district", Journal of Cleaner Production, Vol. 19, No. 13, pp. 1426-1437.

Zhang, B., Bi, J., and Liu, B. (2009), "Drivers and barriers to engage enterprises in environmental management initiatives in Suzhou Industrial Park, China", Frontiers of Environmental Science \& Engineering in China, Vol. 3 No. 2, pp. 210-220.

Zhang, J., Zhang, Z., Ballesteros-Pérez, P., Skitmore, M., Yang, G., Philbin, S. P., and Lu, Q. (2021), "Factors influencing environmental performance: a bibliometric review and future research agenda", International Journal of Urban Sciences, pp. 1-27.

Zhao, H. Z., Ma, A. J., Liang, X. G., Shi, P. L., and Meng, F. S. (2012), "Post-project-analysis in Environmental Impact of the Ecological Construction Projects", Procedia Environmental Sciences, Vol. 13, pp. 1754-1759.

Zheng, S., Wang, J., Sun, C., Zhang, X., and Kahn, M. E. (2019), “Air pollution lowers Chinese urbanites' expressed happiness on social media", Nature Human Behaviour, Vol. 3 No. 3 , pp. 237-243.

Zhu, Q., Cordeiro, J., and Sarkis, J. (2013), “Institutional pressures, dynamic capabilities and environmental management systems: Investigating the ISO 9000-Environmental management system implementation linkage", Journal of Environmental Management, Vol. 114, pp. 232-242.

Ziegler, A., and Rennings, K. (2004), "Determinants of environmental innovations in Germany: Do organisational measures matter?", ZEW-Centre for European Economic Research Discussion Paper, pp. 4-30.

Zutshi, A., and Sohal, A. (2004), "Environmental management system adoption by Australasian organisations: Part 1: Reasons, benefits and impediments", Technovation, Vol. 24 No. 4, pp. $335-357$. 

Table 1: Summary of Literature Review

\begin{tabular}{|c|c|c|c|c|c|c|c|c|c|c|c|c|c|c|c|c|c|c|c|c|c|}
\hline Code & Drivers & 1 & 2 & 3 & 4 & 5 & 6 & 7 & 8 & 9 & 10 & 11 & 12 & 13 & 14 & 15 & 16 & 17 & 18 & 19 & 20 \\
\hline$\overline{\mathrm{D} 1}$ & Training and education & $\checkmark$ & $\checkmark$ & $\checkmark$ & & $\checkmark$ & $\checkmark$ & & $\checkmark$ & $\checkmark$ & $\checkmark$ & $\checkmark$ & $\checkmark$ & $\checkmark$ & $\checkmark$ & $\checkmark$ & $\checkmark$ & $\checkmark$ & $\checkmark$ & & $\checkmark$ \\
\hline D2 & $\begin{array}{l}\text { Adapting EMS to the Nigerian } \\
\text { system }\end{array}$ & & $\checkmark$ & & & & & & & & & & & & & & & & & & \\
\hline D3 & Efficient organisational structure & & & & & & $\checkmark$ & & $\checkmark$ & $\checkmark$ & & & $\checkmark$ & & $\checkmark$ & $\checkmark$ & & & & & $\checkmark$ \\
\hline D4 & Teamwork & & & & & & & & & & & & $\checkmark$ & & & & & $\checkmark$ & & & \\
\hline D5 & Organisational communication & $\checkmark$ & $\checkmark$ & $\checkmark$ & & & $\checkmark$ & & $\checkmark$ & & & & $\checkmark$ & & $\checkmark$ & & & $\checkmark$ & $\checkmark$ & & $\checkmark$ \\
\hline D6 & Employee empowerment & $\checkmark$ & & & & & & $\checkmark$ & & & $\checkmark$ & & $\checkmark$ & & & & $\checkmark$ & $\checkmark$ & $\checkmark$ & & \\
\hline D7 & $\begin{array}{l}\text { Environmental performance } \\
\text { tracking }\end{array}$ & & & $\checkmark$ & $\checkmark$ & & & & & & & & $\checkmark$ & $\checkmark$ & & & & & & & \\
\hline D8 & EMS audit & & $\checkmark$ & $\checkmark$ & $\checkmark$ & & $\checkmark$ & $\checkmark$ & & & & & & $\checkmark$ & & & & & & & \\
\hline D9 & $\begin{array}{l}\text { Top management commitment and } \\
\text { support }\end{array}$ & $\checkmark$ & & $\checkmark$ & & $\checkmark$ & & & $\checkmark$ & $\checkmark$ & $\checkmark$ & & $\checkmark$ & $\checkmark$ & $\checkmark$ & $\checkmark$ & $\checkmark$ & $\checkmark$ & $\checkmark$ & $\checkmark$ & \\
\hline D10 & Recognition \& reward & & & & & & $\checkmark$ & $\checkmark$ & $\checkmark$ & $\checkmark$ & $\checkmark$ & & $\checkmark$ & & $\checkmark$ & $\checkmark$ & & $\checkmark$ & & & \\
\hline D11 & $\begin{array}{l}\text { Availability of ISO } 14001 \\
\text { documents }\end{array}$ & & $\checkmark$ & $\checkmark$ & & & & $\checkmark$ & $\checkmark$ & & & & & $\checkmark$ & $\checkmark$ & & & & & $\checkmark$ & $\checkmark$ \\
\hline
\end{tabular}

D12 Organisational culture

1= Agan et al. (2013); $2=$ Lo-Iacono-Ferreira et al. (2018); $3=$ Mazzi et al. (2016); $4=$ Breslow (2015); $5=$ Ololade and Rametse (2017); $6=$ Hoffman et al. (2012); $7=$ Opoku et al. (2019); $8=$ Testa et al. (2011); $9=$ Moorthy et al. (2012); $10=$ Razumova et al. (2015); $11=$ Bravi et al. (2020); $12=$ Zeng et al. (2011); $13=$ Ammenberg and Sundin (2005); 14 = Massoud et al. (2010); 15 = Moorthy et al. (2012); $16=$ Qi et al. (2011); 17 = Durdyev et al. (2018); 18=Ferdous et al. (2019); 19= Griffith and Bhutto (2008); $20=$ Zhang et al. (2009). 
Table 2: Drivers of Environmental Manage ment System

\begin{tabular}{|c|c|c|c|c|c|c|c|c|c|c|c|c|c|c|c|c|}
\hline \multirow{2}{*}{ Drivers } & \multicolumn{3}{|c|}{ Overall } & \multicolumn{3}{|c|}{ Micro enterprises } & \multicolumn{3}{|c|}{ Small enterprises } & \multicolumn{3}{|c|}{ Medium enterprises } & \multicolumn{3}{|c|}{ Large enterprises } & \multirow{2}{*}{ Sig. } \\
\hline & Mean & SD & $\mathbf{R k}$ & Mean & SD & $\mathbf{R k}$ & Mean & SD & $\mathbf{R k}$ & Mean & SD & $\mathbf{R k}$ & Mean & SD & $\mathbf{R k}$ & \\
\hline D1-Training and education & 6.08 & 1.06 & 1 & 5.75 & 1.25 & 5 & 5.94 & 1.07 & 3 & 6.00 & 0.92 & 7 & 6.71 & 0.49 & 1 & 0.060 \\
\hline D4-Teamwork & 6.03 & 1.07 & 2 & 5.58 & 1.18 & 9 & 5.94 & 1.07 & 3 & 6.05 & 1.15 & 6 & 5.71 & 0.95 & 12 & 0.103 \\
\hline D2-Adapting EMS to the Nigerian system & 5.95 & 1.20 & 3 & 5.82 & 1.11 & 1 & 5.91 & 1.16 & 6 & 5.95 & 1.13 & 12 & 6.29 & 0.49 & 5 & 0.141 \\
\hline D7-Environmental performance tracking & 5.94 & 1.10 & 4 & 5.78 & 1.27 & 3 & 6.09 & 0.93 & 1 & 6.50 & 0.76 & 1 & 6.29 & 0.95 & 8 & 0.144 \\
\hline D9-Top management commitment and support & 5.91 & 1.09 & 5 & 5.78 & 0.99 & 2 & 5.85 & 1.08 & 7 & 6.10 & 0.91 & 5 & 6.14 & 0.38 & 10 & 0.831 \\
\hline D6-Employee empowerment & 5.90 & 0.98 & 6 & 5.72 & 1.23 & 6 & 6.09 & 1.00 & 2 & 6.30 & 0.80 & 3 & 6.57 & 0.79 & 2 & 0.628 \\
\hline D5-Organisational communication & 5.88 & 1.10 & 7 & 5.49 & 1.27 & 11 & 5.74 & 1.19 & 9 & 6.00 & 1.08 & 10 & 6.00 & 1.00 & 11 & 0.602 \\
\hline D3-Efficient organisational structure & 5.80 & 1.12 & 8 & 5.53 & 1.11 & 10 & 5.64 & 1.17 & 11 & 6.00 & 0.92 & 7 & 6.43 & 0.53 & 4 & 0.383 \\
\hline D8-EMS audit & 5.79 & 0.99 & 9 & 5.69 & 1.21 & 7 & 5.94 & 1.13 & 5 & 5.95 & 1.00 & 11 & 6.29 & 0.49 & 5 & 0.298 \\
\hline D12-Organisational culture & 5.74 & 1.08 & 10 & 5.36 & 1.10 & 12 & 5.62 & 1.26 & 12 & 6.35 & 1.04 & 2 & 6.29 & 0.49 & 5 & 0.104 \\
\hline D11-Availability of ISO 14001 documents & 5.73 & 1.17 & 11 & 5.78 & 1.31 & 4 & 5.85 & 1.10 & 8 & 6.26 & 1.19 & 4 & 6.57 & 0.79 & 2 & $0.002 *$ \\
\hline D10-Recognition \& reward & 5.71 & 1.18 & 12 & 5.67 & 1.04 & 8 & 5.71 & 0.97 & 10 & 6.00 & 0.92 & 7 & 6.14 & 1.07 & 9 & 0.525 \\
\hline
\end{tabular}

Note: $\mathrm{SD}=$ Standard deviation; $\mathrm{Rk}=$ Rank; $*$ Significant at 0.05 level 
Table 3: Opinions of Different Professionals on the Drivers of Environmental Management System

\begin{tabular}{|c|c|c|c|c|c|c|c|c|c|c|c|c|c|c|c|c|c|c|c|}
\hline \multirow[b]{2}{*}{ Drivers } & \multicolumn{3}{|c|}{ Overall } & \multicolumn{3}{|c|}{ Architects } & \multicolumn{3}{|c|}{ Project managers } & \multicolumn{3}{|c|}{ Quantity surveyors } & \multicolumn{3}{|c|}{ Builders } & \multicolumn{3}{|c|}{ Engineers } & \multirow[b]{2}{*}{ Sig. } \\
\hline & Mean & SD & $\mathbf{R k}$ & Mean & SD & $\mathbf{R k}$ & Mean & SD & Rk & Mean & SD & $\mathbf{R k}$ & Mean & SD & $\mathbf{R k}$ & Mean & SD & $\mathbf{R k}$ & \\
\hline D1-Training and education & 6.08 & 1.06 & 1 & 6.07 & 0.88 & 2 & 6.00 & 1.00 & 4 & 6.05 & 1.18 & 1 & 6.50 & 0.58 & 2 & 6.18 & 0.87 & 9 & 0.994 \\
\hline D4-Teamwork & 6.03 & 1.07 & 2 & 5.93 & 1.03 & 6 & 6.00 & 1.00 & 4 & 5.97 & 1.17 & 2 & 6.50 & 0.58 & 2 & 6.36 & 0.67 & 7 & 0.994 \\
\hline D7-Environmental performance tracking & 5.94 & 1.10 & 4 & 6.13 & 0.83 & 1 & 5.71 & 0.95 & 7 & 5.76 & 1.22 & 7 & 6.00 & 0.82 & 10 & 6.73 & 0.47 & 1 & $0.047 *$ \\
\hline $\begin{array}{l}\text { D9-Top management commitment and } \\
\text { support }\end{array}$ & 5.91 & 1.09 & 5 & 6.00 & 1.11 & 5 & 6.00 & 0.82 & 3 & 5.83 & 1.19 & 4 & 6.50 & 0.58 & 2 & 6.00 & 0.89 & 12 & 0.862 \\
\hline D6-Employee empowerment & 5.90 & 0.98 & 6 & 6.00 & 0.76 & 4 & 6.14 & 0.69 & 1 & 5.76 & 1.09 & 6 & 6.25 & 0.96 & 9 & 6.18 & 0.75 & 8 & 0.819 \\
\hline D3-Efficient organisational structure & 5.80 & 1.12 & 8 & 5.87 & 0.99 & 8 & 5.29 & 1.11 & 12 & 5.68 & 1.21 & 10 & 6.75 & 0.50 & 1 & 6.36 & 0.50 & 5 & 0.305 \\
\hline D8-EMS audit & 5.79 & 0.99 & 9 & 5.53 & 0.92 & 10 & 6.00 & 1.00 & 4 & 5.68 & 1.06 & 9 & 6.25 & 0.50 & 8 & 6.45 & 0.52 & 3 & 0.330 \\
\hline D12-Organisational culture & 5.74 & 1.08 & 10 & 5.33 & 1.11 & 11 & 5.71 & 0.95 & 7 & 5.71 & 1.15 & 8 & 6.00 & 0.82 & 10 & 6.36 & 0.50 & 5 & 0.928 \\
\hline D11-Availability of ISO 14001 documents & 5.73 & 1.17 & 11 & 5.33 & 1.11 & 11 & 6.14 & 0.90 & 2 & 5.59 & 1.26 & 12 & 6.50 & 0.58 & 2 & 6.45 & 0.52 & 3 & 0.570 \\
\hline D10-Recognition \& reward & 5.71 & 1.18 & 12 & 5.80 & 1.01 & 9 & 5.57 & 1.27 & 10 & 5.62 & 1.28 & 11 & 5.50 & 0.58 & 12 & 6.18 & 0.98 & 10 & 0.241 \\
\hline
\end{tabular}

Note: $\mathrm{SD}=$ Standard deviation; $\mathrm{Rk}=$ Rank; * Signi ficant at 0.05 level 
Table 4: Post Hoc Test of Availability of ISO 14001 Docume nts

\begin{tabular}{lccccc}
\hline & $\begin{array}{c}\text { Test } \\
\text { Statistic }\end{array}$ & S.E. & $\begin{array}{c}\text { Std. Test } \\
\text { Statistics }\end{array}$ & Sig. & $\begin{array}{c}\text { Adj. } \\
\text { Sig. }\end{array}$ \\
\hline $\begin{array}{l}\text { Less than 10 staff - 10 to 49 staff } \\
\text { Less than 10 staff - 50 to 199 }\end{array}$ & -7.508 & 6.409 & -1.172 & 0.241 & 1.000 \\
staff & -27.111 & 7.600 & -3.567 & 0.000 & $0.002 *$ \\
Less than 10 staff - Above 199 & -21.754 & 11.070 & -1.965 & 0.049 & 0.296 \\
staff & & & & & \\
10 to 49 staff - 50 to 199 staff & -19.603 & 7.676 & -2.554 & 0.011 & 0.064 \\
10 to 49 staff - Above 199 staff & -14.246 & 11.123 & -1.281 & 0.200 & 1.000 \\
50 to 199 staff - Above 199 staff & 5.357 & 11.849 & 0.452 & 0.651 & 1.000 \\
\hline
\end{tabular}

Note: S.E. $=$ Standard error; $*=$ Significant at the 0.05 level. 
Table 5: Post Hoc Test of Environmental Performance Tracking

\begin{tabular}{|c|c|c|c|c|c|}
\hline & $\begin{array}{c}\text { Test } \\
\text { Statistic }\end{array}$ & S.E. & $\begin{array}{l}\text { Std. Test } \\
\text { Statistics }\end{array}$ & Sig. & $\begin{array}{l}\text { Adj. } \\
\text { Sig. }\end{array}$ \\
\hline $\begin{array}{l}\text { Project managers - Quantity } \\
\text { surveyors }\end{array}$ & 5.280 & 10.568 & 0.500 & $\begin{array}{l}0.61 \\
7\end{array}$ & 1.000 \\
\hline Project managers - Builders & 7.625 & 16.570 & 0.460 & $\begin{array}{l}0.64 \\
5\end{array}$ & 1.000 \\
\hline Project managers - Architects & 12.267 & 12.101 & 1.014 & $\begin{array}{l}0.31 \\
1\end{array}$ & 1.000 \\
\hline Project managers - Engineers & 30.727 & 12.782 & 2.404 & $\begin{array}{l}0.01 \\
6\end{array}$ & 0.162 \\
\hline Quantity Surveyors - Builders & -2.345 & 13.659 & -0.172 & $\begin{array}{l}0.86 \\
4\end{array}$ & 1.000 \\
\hline Quantity Surveyors - Architects & -6.987 & 7.645 & -0.914 & $\begin{array}{l}0.36 \\
1\end{array}$ & 1.000 \\
\hline Quantity surveyors - Engineers & -25.448 & 8.682 & -2.931 & $\begin{array}{l}0.00 \\
3\end{array}$ & $0.034 *$ \\
\hline Builders - Architects & 4.642 & 14.877 & 0.312 & $\begin{array}{l}0.75 \\
5\end{array}$ & 1.000 \\
\hline Builders - Engineers & -23.102 & 15.436 & -1.497 & $\begin{array}{l}0.13 \\
4\end{array}$ & 1.000 \\
\hline Architects - Engineers & -18.461 & 10.494 & -1.759 & $\begin{array}{l}0.07 \\
9 \\
\end{array}$ & 0.786 \\
\hline
\end{tabular}

Note: S.E. $=$ Standard error; $*=$ Significant at the 0.05 level. 
Table 6: KMO and Bartlett's Test

\begin{tabular}{lrr}
\hline \multicolumn{2}{l}{ Kaiser-Meyer-Olkin Measure of Sampling Adequacy. } & 0.929 \\
\hline Bartlett's Test of Sphericity & Approx. Chi-Square & 836.552 \\
& Df & 66 \\
& Sig. & 0.000 \\
\hline
\end{tabular}


Table 7: Factor Analysis of Drivers of EMS Imple mentation

\begin{tabular}{|c|c|c|c|c|c|}
\hline \multirow{2}{*}{ Code } & \multirow{2}{*}{ Drivers } & \multicolumn{3}{|c|}{ Component } & \multirow{2}{*}{ Alpha } \\
\hline & & 1 & 2 & 3 & \\
\hline D1 & Training and Education & 0.825 & & & 0.761 \\
\hline D6 & Employee empowerment & 0.734 & & & \\
\hline D9 & Top management commitment and support & 0.688 & & & \\
\hline D4 & Teamwork & 0.632 & & & \\
\hline D5 & Organisational communication & 0.543 & & & 0.897 \\
\hline D8 & EMS audit & & 0.825 & & \\
\hline D11 & Availability of ISO 14001 document & & 0.790 & & \\
\hline D2 & Adapting EMS to the Nigerian system & & 0.747 & & \\
\hline D12 & Organisational culture & & 0.570 & & \\
\hline D10 & Recognition \& reward & & & 0.784 & 0.712 \\
\hline D3 & Efficient organisational structure & & & 0.745 & \\
\hline D7 & Environmental performance tracking & & & 0.555 & \\
\hline
\end{tabular}

